\title{
DISKUSSIE
}

Dr. D. Kempff skryf oor

\section{SANG IN DIE EREDIENS}

Die bewering is al gemaak dat die ontstaansrede van die Gereformeerde Kerk in 1859 lê by die saak van Gesange - of die verpligting om dit te sing. So word dit meesal deur nie-Gereformeerdes gestel en oningeligte Gereformeerdes stem dan daarmee saam. Maar dit is onhistories en onwetenskaplik om daaraan vas te klou of nog steeds so te sê. Die saak van die Gesange was natuurlik 'n punt op die agenda, miskien selfs prakties 'n maklik-aanwysbare item, maar nie die enigste nie. Daaragter het 'n belangrike geheel van besware en gevoelighede oor afwyking in leer en verkeerde opset in kerkregering gelê. Dit is ook 'n geweldige verskraling om die Gereformeerde Kerk se bestaan aan nie-gesange-sing en aan reaksie-net-daarteen te verbind.

Nou het ons iets in hierdie rigting in 'n boek wat pas verskyn het: $E k$ sing 'n lofsang by my snare *. Dit is 'n gewone lidmaat wat hiermee sy oortuiging oor die sang in die erediens stel. Natuurlik is dit goed as nie-teoloë hulle oor sake van die geloof en kerk wil uitlaat en dis ' $n$ gebrek as gelowiges agter predikante by standpuntinnamestelling wegkruip. Daarom kan hierdie publikasie wel verwelkom word.

Nog 'n groot meriete van hierdie werk is dat dit vol van liefde vir die Psalms is en die aandag pragtig op die plek en betekenis van die Psalmboek in die Bybel en van Psalmsang in die erediens vestig. Die gevaar bedreig steeds die kerk (bestaande uit - verloste - sondaarmense) dat die lidmate in 'n sleurgang kom en nie meer hulle ryk besit waardeer of sinvol gebruik nie. In hierdie opsig is die aanskaf en lees van die betoog aan te beveel.

Dit is ongelukkig ook noodsaaklik om skerp kritiek uit te spreek, sodat die oë vir die foute oop is en 'n verkeerde invloed oor sake nie ongemerk kan deursuur nie. Hierdie boek wil bewys dat in die erediens net Psalms (dus 150) gesing mág word-en dat selfs Skrifberymings nie daarin 'n plek het nie. Sorgvuldige oorweging van die beredenering dwing my egter tot die oortuiging dat Van Wyk en Kruger nie slaag nie. Dit geld op verskillende terreine waarvan net 'n paar sakies hierna aangestip word.

Historiese sake

Dit kan nié uit die geskiedenis bewys word dat die Gereformeerde kerke net Psalms gesing het of wou sing nie. Hiervoor kan onder meer op die volgende gewys word:

* Calvyn bring in 1539 'n bundeltjie uit sodat die gemeente self kan sing. Daarin is 18 Psalms en 3 andere - Wet, 12 Artikels, Lofsang van Simeon (by J. D. du Toit, Vers. Werke 1, Dl. 7, p. 197) - terwyl Van Wyk van 'n totaal van 18 praat (p. 89). En 
in 1543 voeg Calvyn nog 2 by - Ons Vader en Lofsang-Engele. Knox gebruik later die Psalmbundel van Genéve plus nog 6 (Bouwman, II p. 502).

$\star \quad$ In Nederland het Datheen in sy beryming die 150 plus 6 (en Utenhove se Bedesang voor predikasie). Marnix maak later sy eie beryming en neem daarby ' $n$ hele aantal Ou- en Nuwe-Testamentiese liedere by, én die Geloofsbelydenis (totaal van 150 plus 21). Dit is wel opvallend dat Van Wyk en Kruger geen verantwoording oor hierdie aspek van Marnix se beryming het nie.

$\star$ Die Dordtse Sinode het op sy 162e sitting bepaal dat in die kerke alleen gesing word die 150 Psalms plus Wet, Ons Vader, 12 Artikels, Lofsange Maria, Sagaria en Simeon. Nou beweer Kruger ( $p .95,111)$ dat Dordt hierdie berymings ter wille van die guns van die owerheid toelaat - maar geen bewys of dokumentering word hiervoor gebied nie. Dit is opvallend dat Wagenaar in sy boek oor Dordt (p. 381) sê dat die invoering van tweede Christelike feesdae (bv. Paasmaandag en Pinkstermaandag) gebeur het „om de overheid te pleizieren”. Maar hierdie rede geld tog nie vir die bepaling van wat in eredienste gesing word, vir verpligte gebruik van Doopformulier en opstel van Doopformulier vir bejaardes (alles in dieselfde sitting afgehandel) nie!

$\star$ J. D. du Toit haal Nederlandse deputate aan $(7, p .133)$ wat kom met Voetius se stelling dat die Gereformeerde Kerk in Nederland nooit 'n prinsipiële uitspraak gemaak het dat nét Psalms gesing mag word nie. Maar Marnix het al gesê hulle sing net wat regstreeks uit die Skrif (OT en NT) ontleen is. (Hierby moet gesê word dat Van Wyk en Kruger glad nie ingaan op argumentasie van J. D. du Toit nie en dit kan seker as onwetenskaplik aangemerk word).

* Daar word gestel dat alles nie presies kerkordelik toegegaan het sy sinodebesluite in GKSA oor invoering van Skrifberymings nie (Kruger, p. 96-109). Daarby word skerp woorde oor 'n kerklike vergadering gepubliseer (p. 105). In elk geval is geen beginselgrens met invoering van Skrifberymings oorskry nie en dit is kerkordelik beter om sulke heftige kritiek by wyse van 'n beswaarskrif te lug.

\section{Skrifgegewens}

Die Skrif het beslis net een bundel van liedere (Psalms), terwyl ander liedere, lofsange, weeklagtes in verskeie boeke van $\mathrm{Ou}$ en Nuwe Testament voorkom. Daarom is dit so dat 'n kerk wat nie hierdie bundel gebruik nie of wat dit afskeep, homself tekort doen en geestelike skade ly. J. D. du Toit het hieroor opgemerk (kyk 7, p. 190) dat hy ook vir die Psalms ywer, hy hom ook inspan dat die Psalms nie sal agterbly nie, hy ook meen dat die Psalms hoofskottel in ons sangbundel moet bly. 
Dit is egter heeltemal ' $n$ ander saak as Van Wyk met die bewering kom dat die Skrif duidelik stel dat net Psalms in die erediens gesing mag word. Let maar op hierdie punte:

$\star \quad$ Die Heilige Gees het die boek van die Psalms vir tempelgebruik bestem p. 6). Hiervoor word geen bewys uit die Skrif gegee nie, maar dit is 'n skarnierpunt vir net-Psalms-in-die-erediens.

* As Gereformeerdes hou ons aan die volkomenheid van die Heilige Skrif vas. Laat ons dan tog buig onder die wyse bestel van die Here dat aan die Psalms geen ander geinspireerde liedere toegevoeg is nie en laat ons die genoegsaamheid en volkomenheid van die Psalms as tempelsange erken (p.7). Daar word erken dat enkele persone by die verskyning van die Messias gesing het, maar geen bundel N.T.-liedere is toegevoeg nie. Daar was geïnspireerde sangers maar geen bundel nie, maar dit is nie 'n afdoende argument nie.

* Die Here verag die feeste van Israel en wil niks van die geraas van hulle liedere hoor nie, volgens Amos 5; daarby word Calvyn betrek waar hy praat van mense wat geen grense ken en dus vry is om eie vorme van erediens uit te dink en ' $n$ onbeperkte hoeveelheid liedere te maak (p. 11, 12). Waar Calvyn self buite die Psalmbundel vir kerksang gegaan het, moet ons dit stellig so verstaan: God is teen eiewillige erediens en dis beter om te hou by beryming van wat God in die Skrif (as geïnspireerde lied - ook buite Psalms) gegee het.

* Daar is maar één genadeverbond, één verbondshoof, één Bybel, één liturgie (pasga word nagmaal en besnydenis word doop), één lied, die kanonieke boek van die Psalms wat deur Christus gehandhaaf word (p. 31). Tog moet ons erken dat dit juis Christus is wat die Nuwe Testament, met sy liedere, aan sy kerk gegee het.

* Alle leuenagtigheid en gekunsteldheid in die erediens moet uitgeroei word. "Dit verklaar ook waarom Calvyn hom aan slegs die Psalms as lied in die erediens gehou het" (p. 44). Met die eerste kan ons saamstem, maar byvoeg dat Skrifberymings tog nie noodwendig daardeur geraak is nie; en die tweede stelling is tog nie waar nie.

Dit is onmoontlik en ondoenlik om op verdere punte in te gaan. My eintlike beswaar teen Van Wyk se bewysvoering is dat dit ' $n$ sirkelredenering bevat - eers veronderstel hy om sekere sake in die Skrif te vind (of: hy lees dit daarin) en vervolgens lei hy dit daaruit af. Laat ons maar vashou aan wat die Gereformeerde vaders oor eeue gesê het: Bly vir kerksang by dit waarvan teks in die Bybel gegee is (in Psalms en ander sange van geinspireerde mense), want dit gee diepte aan die lied en vrywaar veel beter teen dwaalleer.

DION KEMPFF.

",Ek sing 'n lofsang by my snare"; die Psalms as lied in die erediens, deur T. G. van Wyk, met enkele hoofstukke deur L. S. Kruger (Pretoria; uitgegee deur die skrywer; 1979. 125 p. R3,36). 